\title{
Increasing the health of the disadvantaged Indonesians through the dana sehat (health funding) program as a contribution to Integrated Microfinance Management
}

\author{
Raini Diah Susanti ${ }^{1,2, *}$ \\ ${ }^{1}$ Leiden Ethnosystems and Development Programm Leiden University The Netherlands \\ ${ }^{2}$ Community Health Nursing Department, Faculty of Nursing Universitas Padjadjaran Indonesia \\ *Corresponding author: r.raini.diah.susanti@umail.leidenuniv.nl
}

\section{ABSTRACT}

Such socio-demographic change has largely been attributed to a situation in which poor people have become more prone to any type of ailment. By consequence, it is necessary for the government to address the specific health needs of the disadvantaged population in the country. This literature review seeks in particular to identify and discuss the dana sehat (health funding program) as a collective community-based initiative and approach to address situation by assessing its implementation, virtues and shortcomings in order to a formulate recommendations for policy makers in their integrated strategies of combining different community services with a view to reduce poverty in Indonesia. The Dana Sehat program has shown self-reliant and invoke active involvement from the community members at local levels in terms of sharing financial responsibility in order to safeguard the sustainability of the program, both between the wealthy and the poor. However, the Dana Sehat program has been disappointing in few areas, such as poor socialization about the program benefits to the consumers, the absence of a legal framework, and minimum supervision, which cause the decline in the number of participants. There is a compelling need to revitalize the dana sehat program by developing integrated strategies to address complicated issues of various financial which hinder sustainable community development as a means to become more effective to help the poor to improve their health and well-being.

Keywords - community financing, dana sehat, health funding, integrated strategies, poverty reduction, community based initiatives.

\section{INTRODUCTION}

Such socio-demographic change has largely been attributed to a situation in which poor people have become more prone to any ailment as the result of their inability to access appropriate treatment, especially for chronic diseases where long-term and multi-level medical care is required (World Health Organization, 2016). By consequence, it is necessary for the government to address the specific health needs of the disadvantaged population in the country, not only to acknowledge that health is a fundamental human right for all, but also an investment in the country at large (Argadiredja 2002). Central Statistics Bureau (BPS) in March 2015 recorded that 11.22 percent or 28.59 million people still live in poverty. In fact, since the beginning of the 1970s the government has been aggressively implementing various programs to reduce poverty. The issue of poverty in Indonesia has not been resolved, especially since the economic crisis in 1997. The poverty has become a complicated situation and multidimensional. Accordingly, efforts to eradicate poverty must be comprehensive, covering integrated various aspects of community life and could be implemented (Slikkerveer, 2011). This paper seeks in particular to identify and discuss the dana sehat (health funding program) as a collective community-based initiative and approach to address the above-mentioned situation by assessing its implementation, and virtues and shortcomings in order to a formulate recommendations for policy makers in their integrated strategies of combining different community services with a view to reduce poverty in Indonesia. 


\section{METHOD}

Systematic review of literature which are taken between 1980 and 2016, from various databases on relevant articles by using keywords "poverty reduction", "community financing".

\section{RESULTS}

\section{Challenges and Poverty Alleviation Strategies in Indonesia}

The greatest burden of poverty lies in particular groups such as women. In general, women bear the burden of life because they rely mostly on a man or dependent parents. As a result, the quality regarding economy and education is very low. One of the prerequisites for the success of poverty reduction is to identify appropriate target groups and regions (T.Hapsari \& Sari, 2007). Reduction and recovery depending on the fate of the poor are the first step statutes determine the demographic and geographic profiles. There are at least two main strategies should be adopted by the government; protect lowincome family and communities through the fulfilment of their basic needs, and empower them to increase the ability to engage in employment thus prevent the creation of new poverty (Djannata \& Atmanti, 2011; Syawie (2011). Poverty reduction policies are made to encourage people to be more empowered, instead of a being dependent (Purwanto, 2007; Slikkerveer, 2011).

Poverty alleviation policies in health need to consider the cycle of poverty and disease, where poverty can cause a person to be susceptible to illness and pain, on the other hand could cause poverty (Argadireja 2002). The number of poor people increases causes the government's expenditure significantly (World Bank, 2008). In 2014 the government had to provide health insurance premium as much as 86.4 million for the poor and near-poor category. BPS (2015) data shows that in fact during in 2013 there was a rise in the poverty gap index from $1.75 \%$ to $1.89 \%$ and the poverty severity index from $0.43 \%$ to $0.48 \%$. The poverty levels of the Indonesian population is getting worse, because they are further away from the poverty line, and inequality of the population spending between poor and non-poor was widening. Although the quality of public health has improved nationally, but the disparity in health status between socioeconomic level and regions is still quite high. The infant mortality rate and under-five mortality rate in the poorest group are almost four times greater than those are among the richest group. Also, the children mortality rate and maternal mortality rate is higher in rural areas, in the eastern part of Indonesia, as well as in the population with low education levels. Percentage of children with the malnutrition and poor status in rural areas was higher than urban areas (Ministry of Health RI, 2015).

Slikkerveer (2011) and Argadireja (2002); state in which the government has put through a variety of policies and efforts in addressing poverty in Indonesia. Particularly in the health sector since the New Order government until the current administration, starting with Inpres Desa Tertinggal (IDT) in 1994, providing micro-credit to small businesses, increase the minimum wage, implement the additional food program to improve nutrition of toddlers and pregnant women, and prevent the deaths of mothers and babies through the empowerment of female cadres in the community. At the time of the Habibie's administration (1998-1999) began to introduce the Social Safety Net program to reduce poverty, increase government subsidies for basic needs, provide education budget, provide scholarships, job opportunities and increase revenue income civil servants. Further during the leadership Abdurrahman Wahid (1999-2002), a government provided subsidy of basic needs for the poor through the provision of health services, so called the Social Safety Net Health (JPS-BKJPKM), education, and housing, increased the income of civil servants, subsidies for water supply, education, public transport compensate for the increased price of oil (PD-PSE-BK) or Subsidy Reduction Compensation Fuels Program (PKPS-BBM-BK). Furthermore, during the reign of Megawati Sukarnoputri (2002-2004) allocated 20 trillion rupiahs to subsidise the poor, reduce electricity rates for the poor, microcredit interest subsidies, housing assistance for the poor, provision of maternal and child health services. Under the President Susilo Bambang Yudhoyono (2004-2009 and 2009-2014), he implemented a policy through direct cash assistance (BLT), a program to reduce unemployment rate, lowerpriced rice program (Raskin), subsidized state-owned enterprises, improve health care through the provision of supplementary food and immunization in rural communities and providing small loans (KUR) for small businesses.

Currently, the government Jokowi (2015-present) is seeking to reduce poverty, especially in the health sector through the implementation of Universal Health Coverage (BPJS) and Health Card Program. All the strategy is done in line with the Millennium Development Goals (MDGs). Hence, poverty remains at large 
(Ministry of Health RI, 2015). While the current MDGs agenda is over and move toward the SDGs 2030 Agenda, which includes 17 goals, the achievement of SDGs in line with the vision and mission of the Indonesian national health development to achieve Indonesia Sovereign, Independent and Personality Based Mutual assistance (gotong-royong). To achieve these objectives, there are 9 priority agenda known as Nawa Cita to be observed in the Working Cabinet derived in two purposes the Ministry of Health in 2015-2019, namely: 1) the increased status and public health; 2) improving the responsiveness and the protection of the public against the risk of social and financial health (Ministry of Health R.I, 2015; WHO 2016).

There are two important factors that could cause poverty alleviation programs in Indonesia to fail. First, poverty reduction programs tend to focus their efforts on the distribution of social assistance for the poor. It was, among others, in the form of rice for the poor and the social safety net (JPKM) for the poor. Efforts like this will be difficult to resolve the problem of poverty that exists due to the nature of the aid that is not for empowerment, and it can even lead to dependence (Slikkerveer, 2011). The assistance programs oriented government's generosity can exacerbate the moral and behavior of the poor. The aid program for the poor should be more focused to grow the culture of a productive economy and can liberate dependence, permanent residents. On the other hand, social assistance programs could also cause corruption in the distribution. It would be better if the aid is directly used to improve the quality of human resources), such as free of school expenses, for students at elementary school and junior high school, as well as the liberation of the costs of treatment at a health center (Puskesmas). The second factor which could lead to failure of the poverty alleviation program is the lack of understanding of the various parties on the causes of poverty itself so that development programs that exist are not based on issues of poverty, which vary locally.

As communicated by Slikkerveer 2011, in order to alleviate poverty there is a need for a strategy that takes into account the local knowledge so that problems encountered can be solved in agreement with the requirements and characteristics of the people concerned. Poverty alleviation efforts are not only to provide direct assistance to the poor because the causes of poverty are not only due to the aspects that are purely materialistic but also because of the vulnerability and lack of access to improve the quality of life of the poor. The approach is intended to empower poor people out of poverty by using the potential and the resources they have. Group-based poverty reduction program of community empowerment is an advanced stage in the process of poverty alleviation. At this juncture, the poor began to realise the capabilities and potentials to get out of poverty. Empowerment approach as an instrument of this program is intended not only do the poor public awareness of the potential and the resources they have but also encourage the poor to participate in a wider scale, especially in the development process in the region. Characteristics of communitybased poverty reduction is as follows: 1) Using a participatory approach; 2) The participatory approach is not just about community participation in the implementation of the program, but also the involvement of the community in every phase of the program, including the process of identification of needs, planning, implementation, and monitoring the implementation of the program, even to the stage of the preservation process of the program; 3) Strengthening the institutional capacity of the public; 4) group based poverty eradication program focuses on enhancing community empowerment aspects of community institutions in order to increase the participation of all elements of society, so that the community is able independently to the development of the construction of what he wanted. Strengthening institutional capacity not only at the stage of organising the community to get their basic needs, but also strengthen social institutions function used in poverty alleviation; 5) The group is self-managed by the community activities and groups.

Tim Nasional Percepatan Penanggulangan Kemiskinan [TNP2K] or National Team for Poverty Alleviation Advancement (2014) describe in which group poverty reduction programs based on community empowerment must foster trust on the poor to always open opportunity society in self-help group, to develop the potential that exists on their own in order to encourage their potential to develop independently, so it is necessary: 1) planning and sustainable development 2) planning program is done openly with the principle of the people, by the people, for the people and the result becomes part of development planning at the village/sub-district, sub-district, district, provincial and national levels. This process requires coordination in conducting policy and control the implementation of the program among stakeholders of poverty reduction program. Coverage program on a group of poverty reduction programs based on community empowerment can be classified by: region, based group conducted in rural-urban areas and areas designated as disadvantaged regions, sectors, groups of 
programs based on community empowerment focuses on strengthening the capacity of poor communities by developing various the scheme rests on a particular sector of society needs in the region. The beneficiaries are groups of people identified as poor. Poor people still have the ability to use their resources.

\section{The Role of Community Health Nurses in Poverty} Alleviation through The Dana Sehat Program

Community health nursing is a professional nursing services aimed at communities with emphasis on highrisk groups in an effort to achieve the degree of optimal health by improving health, disease prevention, health maintenance and rehabilitation to ensure access to health services needed and involve clients as partners in the planning, implementation, and evaluation of nursing services (CHS-Pokja, 1997). A public health nurse has a role to provide nursing services such as nursing care/health for individuals, families, groups, communities in improving health, disease prevention, health recovery and fostering community participation in the framework of self-reliance in the field of health nursing. In this case, a public health nurse to be a part in contributing to improving public health, especially in poor communities in the context of a vulnerable and at risk group for health disturbance as well as enhancing community empowerment. In addressing the health problems of the poor, one of the approaches that have such principles with integrated microfinance management is the Dana Sehat Program (Health Funding Program).

The Dana Sehat is the maintenance of health from the community to the community, which is administered based joint venture and familiarity with the pre-paid financing to improve public health (Depkes RI 1994; Sukeksi \& Nugroho 1998; Bahar 1998). With its distinct characteristic as a community initiative, the Dana Sehat program has shown self-reliant and invokes active involvement from the community members at local levels regarding sharing the financial responsibility to safeguard the sustainability of the program, both between the wealthy and the have-nots and between low and high risk. This program is similar to Health Equity Funds in Cambodia (Peters et al., 2008) and there was also termed Dasolin; Dana Sehat untuk Ibu Bersalin (Health Funding for Maternity), Tabulin; Tabungan untuk Ibu Bersalin (Saving for Maternity) as part of the health financing which has the same principles and the characteristics of the Dana Sehat. This program is only carried out within the framework of Maternal Alert Village program (Desa Siaga Maternal) (Department of
Health RI, 2008; Ambaretnani, 2012). Thus, the Dana Sehat is part of the Integrated Microfinance Management that can be applied to address the particular health problems experienced by the poor. The Dana Sehat program was the approach from the community initiative (bottom-up) so it will be easy to develop and be sustainable. The Dana Sehat Program is already in progress from 1986 in Garut, West Java (Bahar 1998). The Dana Sehat program was implemented in 1998 in 27 provinces, 290 districts and approximately 1500 villages in which covers $5 \%$ of populations. (Sukeksi \& Nugroho 1998).

Bahar (1998) on the implementation of the Dana Sehat in Garut, West Java showed that public attitudes are very positive due to the high nature of mutual aid societies (gotong-royong) and their coaching. This is also supported by the results of the study Sukeksi and Nugroho (1998) which state that the communities still need dana sehat to reason: 1) for the maintenance of good health required a sustainable cost; 2) personal finance prioritize on treatment and neglect preventive measures; and 3) not everyone will be able to pay the health maintenance cost. Johar (2009) revealed in which the majority of Indonesian make health care payment in cash directly out of pocket money. Only less than 20 percent of Indonesia's population has health insurance. Dana Sehat is a form of approach that comes from indigenous knowledge applicable to local communities, as well as gintingan or perelek where the cost can be in the form of a bag of rice or cash (Saefullah, 2011). On the other hand, there is some limitations of the Dana Sehat program perceived by the public, such as the absence of a legal framework. There is still a lack of socialisation and counselling about dana sehat in the community so that most residents do not know the purpose and benefits of health funds so that it can reduce the number of participants. Besides the limitations of the board in managing the resources, lack incentive for management, coaching is still not up to the quality and quantity, and the difficulty of bureaucracy become an obstacle to the implementation of the Dana Sehat (Bahar 1998; Sukeksi \& Nugroho 1998). Unfortunately, this time, the preservation of health fund membership has decreased replaced with a new government policy, so called BPJS, universal health coverage in which applies uniformly to all Indonesian people both rich and poor alike without considering the real needs of each local community is certainly different. So the current policy is a top down are contrary to the principles of integrated microfinance management. While according to the model of Aday and Anderson (1974) reveal that the community 
in reaching health services will certainly consider four dimensions of access to health, as follows: 1) access to service facilities in geographically travel far or near, 2) availability-types of services required are available or not and how long the waiting time required, 3) financial accessibility-types of services provided in accordance with the individual's ability to pay or whether covered by insurance, and 4) acceptability-suitability of health care given to the individual expectations are socially and culturally.

\section{DISCUSSION}

Does BPJS can overcome poverty in Indonesia? Vidyattama, Resosudarmo and Miranti (2014) reveal in the beginning of 2014 disadvantaged Indonesian do not pay to join BPJS as universal health coverage albeit it will reduce out of pocket of health service expenditure. However, the answer is not visible yet because of the new policy lasted less than two years so that it would need further evaluation.

\section{CONCLUDING REMARK}

To sum up, the dana sehat is still interested by the community because of the amount of premium to be paid adjusted for earned income. The preservation of the dana sehat participants are strongly influenced by the promotion of the dana sehat manager, so the function of membership management, financial management, and health care administration manager needs to be improved with the training of integrated microfinance management. There is a compelling need to revitalise the Dana Sehat program by developing integrated strategies to address complicated issues of various financial, medical and educational services at the community level which hinder sustainable community development as a means to become more effective to help the poor to improve their health and well-being.

\section{ACKNOWLEDGEMENT}

I would like to express my gratitude to Prof. Dr. Dr. (h.c.) L. J. Slikkerveer for guidance and brilliant ideas in the writing of this paper and LEAD Programm for funding the publication of this paper. Similarly, I would like thank the Directorate General of Higher Education of Republic Indonesia (DIKTI) for funding support to study in Leiden University and also Universitas Padjadjaran for give me opportunity to study in LeidenThe Netherlands.

\section{REFERENCE}

Aday, L.A and Anderson, R A Framework for the Study of Access to Medical care. Health Serv. Res.3 pp. 208-220;1974.

Ambaretnani, P. Paraji and Bidan in Rancaekek: Integrated Medicine for Advanced Partnerships among Traditional Birth Attendants and Community Midwives in the Sunda Region of West Java, Indonesia, $\mathrm{PhD}$ Dissertation, LEAD, Leiden University; 2012.

Argadireja, D.S. Program Penanggulangan Kemiskinan Bidang Kesehatan, Rakorbangpus Departemen Kesehatan RI, Jakarta; 2002.

Bahar, E.S. Analisis Pelaksanaan Dana Sehat di Kabupaten Garut Jawa Barat (Suatu Studi Kualitatif;1998.

Biro Pusat Statistik Garis Kemiskinan di Indonesia 2013-2015;2015

CHS-POKJA Depdikbud R.I. Pendidikan Tinggi Keperawatan di Indonesia. Dikti. Depkes R.I Jakarta;1997.Dana Sehat JPKM. http://www.ppjk.depkes.go.id/index.php? [Accessed $23^{\text {rd }}$ August 2016].

Departemen Kesehatan R.I Buku Saku Desa Siaga di Provinsi Jawa Barat;2008.

Djannata, A.A and Atmanti, H.D.A Analisis Program Penanggulangan Kemiskinan Menurut SKPD (Satuan Kerja Perangkat Daerah) di Kota Semarang Dengan metode AHP(Analisis Hiraarki Proses). Semarang;2011.

Hamzah, A Kebijakan Penanggulangan Kemiskinan dan Kelaparan di Indonesia : Realita dan Pembelajaran. Jurnal AKK. 2012;1(1):1-55, September 2012.

Johar, M. The impact of the Indonesian health card program: A matching estimator approach. Journal of Health Economics 2009;28 :35-53

Ministry Of Health R. I Rencana Strategis Kementerian Kesehatan Republik Indonesia 2015-2019. Jakarta:2015.

Peters, D.H., Garg, A., Bloom, G., Walker, D.G., Brieger, W.R., and Rahman, M.H (2008) Poverty and 
Access to Health Care in Developing Countries. New York Academy of Science 2008;(1136):161-171.

Purwanto, E.A. (2007) Mengkaji Potensi Usaha Kecil dan Menengah(UKM) untuk Pembuatan Kebijakan Anti Kemiskinan di Indonesia. Jurnal Ilmu Sosial dan Politik Maret 2007:10(3) :295-324

Saefullah, K. Gintingan in the Sunda Region of West Java: The Role of Local Institutions in sustainable Community Management and Development in Subang, Indonesia: 2011.

Slikkerveer, L.J.) Handbook for Lecturers and Tutors of the New Master Course on Integrated Microfinance Management for Poverty Reduction and Sustainable Development in Indonesia. LEADUL/UNPAD/MAICH/GEMA PKM:2011.

Sukeksi and Nugroho, H (1998) Analisis Penurunan Peserta Dana Sehat di Kecamatan Wonogiri. Jurnal Manajemen Pelayanan Kesehatan 1998:01(03).

Syawie, M. Kemiskinan \& Kesenjangan Sosial Informasi 2011:16 (03):7
T. Hapsari, D and Sari, P. Jaminan Pemeliharaan Kesehatan (JPK) Analisis Data Susenas 2004. Media Litbang Kesehatan Xl'II Nomor 1 Tahun 2004

Tim Nasional Percepatan Penanggulangan Kemiskinan [TNP2K] Upaya Khusus Penurunan Tingkat Kemiskinan. Kebijakan Tahun 2014; 2014

Vidyattama, V., Resosudarmo, B.P., Miranti, P. The Role of Health Insurance Membership in Health Service Utilisation in Indonesia. Bulletin of Indonesian Economic Studies 2014:50(3) : 393-413

World Bank. Investing in Indonesia's Health: Challenges and Opportunities for Future Public Spending. Health Public Expenditure Review: 2008.

World Health Organization World Health Statistics 2016 Monitoring Health for Sustainable Development Goals (SDGs):2016. 